\title{
Errors Middle School Students Make When Performing Mathematical Modelling Tasks
}

\author{
Karen Porras \\ Elena Castro-Rodríguez iD b \\ ${ }^{a}$ Universidad Nacional, Facultad de Ciencias Exactas y Naturales, Escuela de Matemática, Heredia, Costa \\ Rica

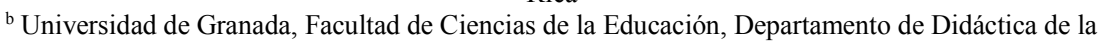 \\ Matemática, Granada, Spain
}

Received for publication on 15 Oct. 2020. Accepted after review on 12 Mar. 2021 Designated editor: Claudia Lisete Oliveira Groenwald

\section{ABSTRACT}

Background: In Costa Rica, since 2012, schoolchildren have been trained in modelling as a fundamental part of the educational curriculum. Objectives: To identify and characterise errors incurred by a group of secondary school students in Costa Rica when applying the mathematical modelling process phases when solving direct proportionality tasks. Design: Through a qualitative approach, specifically a case study, it aims to study the participants' social interpretations. Setting and Participants: The modelling tasks were applied to 24 students attending the 7 th level of middle school education in the province of San José in Costa Rica, when the topic of direct proportionality is deepened and the participants have been instructed in modelling tasks since the first years of elementary school. Data collection and analysis: Information was collected through participants' written productions, researchers' observation, and interviews. Content analysis was carried out through the categorisation proposed by Abrate et al. (2006) to analyse mathematical errors. Results: The participants did not apply all phases of the mathematical modelling process, making more errors due to incorrect or unintended calculations and incorrect associations when solving the mathematical model. Conclusions: We concluded that the errors detected in this work are elements of reflection, progress, and feedback that should encourage the teachers' search for strategies that help solve the deficiencies that emerge when students solve modelling activities.

Keywords. Errors; mathematical modelling; middle school education; direct proportionality.

\section{RESUMEN}

Antecedentes: En Costa Rica, desde el 2012, los escolares se forman en modelización por ser parte fundamental del currículo educativo. Objetivo: Identificar

$\overline{\text { Corresponding author: Karen Porras Lizano. Email: karen.porras.lizano@una.cr }}$ 
y caracterizar los errores en los que incurren un grupo de estudiantes de Educación Secundaria de Costa Rica cuando aplican las fases del proceso de modelización matemática al resolver tareas de proporcionalidad directa. Diseño: Mediante un enfoque cualitativo, específicamente un estudio de casos pues pretende estudiar interpretaciones sociales de los participantes. Entorno y Participantes: Las tareas de modelización se aplicaron a 24 estudiantes del nivel de sétimo de Educación Secundaria de la provincia de San José en Costa Rica, siendo este nivel donde se profundiza el tema de proporcionalidad directa y los participantes han sido instruidos en tareas de modelización desde la educación primaria. Recopilación y Análisis de datos: Se recolectó información a través de las producciones escritas de los participantes, la observación de los investigadores y la realización de entrevistas. Se llevo a cabo un análisis de contenido, utilizando la categorización propuesta por Abrate et al. (2006) para el análisis de errores matemáticos. Resultados: Los participantes no aplicaron todas las fases del proceso de modelización matemática, se obtiene una mayor presencia de errores debidos a cálculos incorrectos o accidentales y asociaciones incorrectas al resolver el modelo matemático. Conclusiones: Se concluye que los errores detectados en este trabajo son elementos de reflexión, avance y retroalimentación que deben incentivar la búsqueda de estrategias por parte de los docentes que ayuden a resolver las deficiencias presentes cuando los estudiantes resuelven actividades de modelización.

Palabras clave. Errores; modelización matemática; educación secundaria; proporcionalidad directa.

\section{RESUMO}

Contexto: Na Costa Rica, desde 2012, os alunos aprendem modelagem, pois é uma parte fundamental do currículo educacional. Objetivos: Neste trabalho propomos identificar e caracterizar os erros cometidos por um grupo de estudantes costarriquenhos ao aplicar as fases do processo de modelagem matemática na resolução de tarefas de proporcionalidade direta. Design: Utilizando uma abordagem qualitativa, especificamente um estudo de caso, visamos estudar as interpretações sociais dos participantes. Ambiente e participantes: As tarefas de modelagem foram aplicadas a 24 alunos do sétimo nível do ensino fundamental II da província de San José na Costa Rica, pois neste nível se aprofunda o tema da proporcionalidade direta, tendo sido os participantes instruídos em tarefas de modelagem desde o ensino fundamental I. Coleta e análise de dados: As informações foram coletadas por meio das produções escritas dos participantes, da observação dos pesquisadores e da realização de entrevistas. Realizamos análise de conteúdo, utilizando a categorização proposta por Abrate et al. (2006) para a análise de erros matemáticos. Resultados: Entre os resultados, destacamos que os participantes não aplicaram todas as fases do processo de modelagem matemática e encontramos maior presença de erros por cálculos incorretos ou acidentais e associações incorretas na resolução do modelo matemático. Conclusões: Concluimos que os erros detectados neste trabalho são elementos de reflexão, evolução e retroalimentação que devem encorajar os professores a procurar estratégias que ajudem a resolver as deficiências presentes quando os alunos resolvem as atividades de modelagem. 
Palavras-Chave: Erros; modelagem matemática; Educação secundária; proporcionalidade direta.

\section{INTRODUCTION}

Education must accept the challenge of equipping students with the skills and abilities to develop in a globalised society. Specifically, mathematical education is critical to developing 21 st-century competencies, such as critical thinking or problem solving. In this area of competence, mathematical modelling acquires a relevant role (Blum \& Niss, 1991; Bosch, Garcia, Gascón \& Higueras, 2006; Lesh \& Doerr, 2003) as a tool used in various scientific fields such as engineering, nanotechnology, economics, biology, or arts to solve complex problems (Sriraman \& Lesh, 2006).

Currently, mathematical modelling has become a fundamental skill that schoolchildren must develop. Proof of this is its incidence in curricular documents of various countries (Araya, 2016), or the annual International Mathematical Modelling Challenge for students. For research, modelling has received increasing attention from the international community through special issues dedicated to this topic in journals such as ZDM (2006 (2-3), 2018 (1-2)), AIEM (2020 (1)) and UNO (2015 (69)), the annual International Conference on Mathematical Modeling and Analysis, or working groups in congresses such as the International Congress on Mathematical Education (ICME), the Congress of the European Society for Research in Mathematics Education (CERME) and specifically, in Spain, the XIII Symposium of the Spanish Society for Research in Mathematics Education (SEIEM).

Costa Rica is one of the countries where mathematical modelling teaching has been developed for years. In 2012, the Costa Rican education system altered the mathematics curriculum for elementary and high school levels (Ministerio de Educación Pública, 2012). One of these modifications was the inclusion of mathematical modelling as a fundamental part of the curriculum. However, in this context, according to the Sexto Informe del Estado de la Educación del Programa Estado Nación/Sixth State-of-Education Report of the Estado Nación Programme (PEN, 2017), 56\% of the lessons that correspond annually to mathematics are lost in activities unrelated to learning. Therefore, we understand that it is necessary to manage teaching time properly to enhance mathematical content learning and improve students' preparation for a professional future (Lopez, Molina, \& Castro, 2017).

To manage the limited time, it is essential to know the students' errors to plan and provide teaching that could prevent them (Magen-Nagar, 2016). 
Based on the inclusion of mathematical modelling as a fundamental part of the curriculum of Costa Rica, and by visualising errors as elements that provide relevant information about the learning process (Fernández \& Brey, 2012), this study aims to identify and characterise the errors made by a group of students in Costa Rica when applying the mathematical modelling phases when solving tasks of simple proportionality.

\section{THEORETICAL FRAMEWORK}

\section{Mistakes in mathematics education}

An important part of the mathematics teaching and learning process is the study of students' errors (Rico, 1998). In mathematics education, errors have had negative connotations and have been characterised as "inappropriate and harmful cognitive schemes for a given situation, are unsuccessful attempts to adapt an acquired knowledge to a new situation and are not only consequences of a specific lack of knowledge or a distraction" (Socas, 1997, pp. 43-44). However, over the last decades, they have acquired particular relevance in the area, adopting diverse approaches and focuses (Magen-Nagar, 2016; Rico, 1998; Socas, 2007). Rico (1998) considers errors as an opportunity because it is through them that schoolchildren express the incomplete nature of their knowledge and help the teacher understand and develop knowledge about the student. The errors are a starting point for educators to propose measures to prevent, detect, address, and solve the deficiencies that prevent students from advancing in their learning (Ruano, Socas, \& Palarea, 2008).

Among the current research lines is the diagnosis, analysis, and documentation of the most common errors, and their classification (Abrate, Pochulu \& Vargas, 2006; Movshovitz-Hadar, Inbar, \& Zaslavksy, 1987; Radatz, 1980). We base this work on the classification proposed by Abrate et al. (2006), supported by the studies of Movshovitz-Hadar et al. (1987) and Radatz (1980), which contemplates the following categories:

1. Errors due to mathematical language: They occur by an incorrect translation between languages, for example, from natural language to formal mathematical language or vice versa.

2. Errors due to student's difficulties to obtain spatial information: Refers to students' errors made when processing information presented in spatial or visual images (iconic representations). 
3. Errors due to incorrect inferences or associations: generated by applying rules and properties valid in similar or related contexts, which occur by reasoning fallacy, not due to specific content. In these circumstances, the student is aware that the situation posed is different from others addressed; however, he/she "invents" new rules or deforms them, deriving the validity of those he/she knows from other situations for the case with which he/she is dealing.

4. Errors due to the recovery of a previous scheme: errors caused by the persistence of some previous aspects of the content or the process of solving a situation, even though the mathematical task is new. In these instances, the student is not aware that the situation is different from others posed, so he/she does not make inferences of the validity of the rules or properties, but rather applies them because he/she considers that he/she is in a known context.

5. Errors due to incorrect or unintended calculations: errors due to unintended situations such as adding strange data or conflicting information, forgetting some data, unnecessary answers, neglecting relevant information when reading a statement, taking incorrect data from a table, or when the entire procedure performed on the task is correct, but the final solution is not. In this case, if the student reviews their work or performs the solution verification process, they may become aware of the error.

6. Possible errors due to deficiencies in the construction of prior knowledge (C6): they are caused by incorrect or inadequate learning of previous facts, skills, and concepts that interfere with proper information processing. In this way, we identified isolated or unintended errors, from which we could not establish a pattern even after interviewing the student.

7. Errors due to the lack of previous knowledge: On this occasion, the cause of the error is the lack of learning of previous facts, skills, and concepts, i.e., the lack of prior knowledge necessary to build a more complex conceptual base - for example, the error due to not knowing the issue involved. Unlike the previous category (possible errors due to deficiencies in the construction of prior knowledge), the student lacks the necessary prior knowledge since he/she was not taught it.

\section{Errors in mathematical modelling activities}

Mathematical modelling is understood as the procedure that starts from a real-world problem, which requires simplification to develop a mathematical model, raise conjectures about it and use mathematics as an instrument to 
develop a response, concluding with the analysis of the results and their contrast with the initial problem (López et al., 2017). According to Lesh and Doerr (2003), this process is developed cyclically through four phases: description (relevant information is understood and systematised), manipulation (the mathematical model representing the problem is obtained and solved), prediction (the results are interpreted and analysed in relation to the conditions of the problem), and validation (the feasibility of solving the mathematical problem is reflected and judged). In modelling activities, the solver's mathematical thinking is involved in complex tasks, requiring "describing, explaining, debating, justifying, predicting, critically listening, and constructively questioning" (English, 2007, p. 8), essential processes for future professional life.

The complexity of mathematical modelling tasks entails a series of students' errors and difficulties that experts in the field have not noticed. However, while most investigations have focused on detecting and categorising the mistakes students made in the problem-solving process, few investigations detect errors made in the modelling process (Brown, Bossé \& Chandler, 2016; Çalişici, 2018; Isik \& Kar, 2012). In this sense, some recent research has been carried out with students at different educational levels such as university students (Brown et al., 2016; Fernández \& Brey, 2012) and middle school students (Çalişici, 2018; Guerrero, 2016; Socas, Ruano \& Hernández, 2016).

Within the university level, the studies by Fernandez and Brey (2012) and Brown et al. (2016) coincide in detecting errors due to incorrect interpretation of the language and the lack of verification of the solution. In the case of Fernández and Brey (2012), they identify and classify mathematical errors of business and management and business administration students and relate them to how they may resonate in their future profession. Errors linked to mathematical content such as the inappropriate use of percentages and decimal numbers, contempt for decimals and errors in calculating time magnitudes, among others, are highlighted. At this same educational level, Brown et al. (2016) analyse the nature of two university students' errors in the context of task solving in a dynamic mathematical environment. The authors present a categorisation of three different types of errors: mastery, process, and interaction. They conclude that students generally need more qualification in to master problem solving to complement instruction in other knowledge domains and in many cases, this may require additional teacher qualification in the problem solving area (Brown et al., 2016). 
At the middle school level, the investigations by Socas et al. (2016) and Guerrero (2016) analyse students' errors when solving mathematical modelling tasks using the Socas model $(1997,2007)$, which proposes three origins for errors: affective attitudes, lack of meaning, and obstacle. In the first study, the results show that students find the modelling process very hard, with their average success rate being $23.74 \%$. Regarding difficulties and errors, the most frequent origin in modelling is the lack of meaning, which emerges in two distinct areas. In one, it is caused by aspects that have remained unresolved in arithmetic or geometry, and in another, the lack of meaning has mostly occurred due to the characteristics of algebraic language in the processes of formal substitution and generalisation. Regarding emotional attitudes, they consider it essential to seek why students have not answered some questions, with attitudinal blockages being the leading cause of errors.

In Guerrero's study (2016), students had no experience in the modelling process. In her results, she obtains that the most frequent errors are: particularisation, made from the lack of meaning because the previous conceptual system is insufficient for students to make sense of the construction of new knowledge, i.e., students do not find meaning in the use of algebraic language, because they continue to think numerically; finally, the incomplete mathematical model due to an oversight in partially solving problems originated in emotional attitudes towards mathematics.

Çalışıcı's study (2018) determines difficulties that 34 students attending the $7^{\text {th }}$ grade of the middle school found to solve reason-proportion problems and suggest applying the envelope technique to improve comprehension and success in solving the problems proposed. These students often make errors such as confusing the direction of the operation in reducing and expanding numbers by raising the proportion. On the other hand, they improve the pace and success of the solution with the technique proposed in the study.

In summary, the investigation of errors in the modelling process has focused on their detection and categorisation (e.g., Brown et al., 2016; Çalişici, 2018; Fernández \& Brey, 2012) and their causes (Guerrero, 2016; Socas et al., 2016), showing that students reveal their deficiencies in mathematical content and problem-solving management and in the mathematical modelling phases. However, in no case had students been specifically instructed in the mathematical modelling procedure, which would contribute to improving the teaching of this process and detecting and treating the errors in a critical and constructive way (English, 2007). Since the Costa Rican education system 
included mathematical modelling as fundamental in the curriculum, in this work, we focus on a group of middle school students who have been instructed throughout their elementary education with this approach. Specifically, we intend to identify and characterise errors made by a group of students in Costa Rica when applying the mathematical modelling phases when solving simple proportionality tasks. We selected this mathematical content because it is a mandatory content within the Ministry of Public Education curriculum of Costa Rica (MEP, 2012) that the students find very challenging (Çalişici, 2018).

\section{METHODOLOGY}

This research has a qualitative character. It is particularly a collective case study because it involves several instrumental case studies to deepen and build the theoretical body: add findings, find common elements and differences, and accumulate information (Stake, 2010).

\section{Participants}

This research involved 24 students from the province of San José in Costa Rica, from a medium-low socioeconomic background and an average age of 13 years. We selected the $7^{\text {th }}$ level because simple proportionality should be offered at that level, according to the Ministry of Public Education curriculum (MEP, 2012). Throughout the first years of elementary education, students have worked on modelling tasks and received instruction on their phases: description, manipulation, prediction, and validation (Lesh \& Doerr, 2003).

\section{Activities proposed}

The mathematical modelling activities used for this study were validated in previous research processes (Porras, 2013; Porras \& Fonseca, 2015) and comply with the principles proposed by Lesh and Doerr (2003) personal significance, model construction, self-assessment, documentation, simple prototype, and generalisation of the model. These principles characterise them as mathematical modelling activities. The first activity, "Cocinando con mi mamá/Cooking with my mom" (see Figure 1), presents the content of proportions applied to cooking a recipe. By increasing the amounts of 
ingredients given, the student must determine the correct amount of 5.5 cups of milk and 110 rolls. ${ }^{1}$

\section{Figure 1}

Activity 1Cooking with my mom. (Porras, 2013, pp. 114)

Carlos' mom enjoys cooking for her family. One day she decided to make homemade bread, the specific recipe that needs 3 cups of flour and one cup of milk, and other ingredients to prepare 20 bread rolls. As her family likes homemade bread very much, she decides to use all the flour she has and when she measures it, she discovers she has 16.5 flour cups. Now, her problem is to discover how many cups of milk and other ingredients she will need exactly to make the recipe. As she knows Carlos likes doing math calculations, she asks him to help her get the right amount she needs.

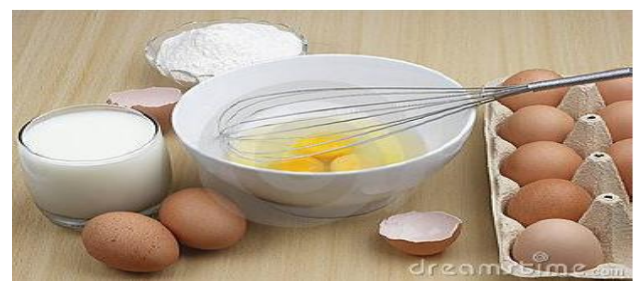

So, how many cups of milk does he tell her she should add? Also, how many bread rolls could she prepare with that amount of ingredients she used?

Write a report to describe the problem solving method used and your conclusions for each of the questions asked. And answer: in which other similar situations could we apply this same reasoning for this problem?

The second activity, "Calculating my allowance" (see Figure 2), must determine the increase to be made to the student's allowance, who has received the same amount of money for ten years. To solve this activity, a table of price items from ten years ago and their current counterpart price is provided. The student is expected to get the correct answer that the increase in the allowance should be approximately three times $\mathbb{C} 2,000$, i.e., $\mathbb{C} 6,000$.

\footnotetext{
${ }^{1}$ In Costa Rica, dots are used for the thousands and commas for the decimals (e.g. 5,5 tazas de harina). For translation purposes, in this text, the numbers and explanations will use commas for the thousands and dots for the decimals, as in the U.S.A (e.g, 5.5 cups of flour).
} 


\section{Figure 2}

Activity 2 Calculating my allowance. (Porras \& Fonseca, 2015, p. 56-57)

Hello! I am Mario, I need your help with my allowance. When my sister Mariela was 13 years old, her allowance was $\mathbb{C} 2,000$, but that was ten years ago. Now I am 13. My parents give me $\mathbb{2} 2,000$ weekly too. I think they should raise my pocket money, as things are more expensive nowadays. In Costa Rica you cannot afford buying the same things my sister bought ten years ago.

To prove my hypothesis, I surveyed the prices from ten years ago of some articles. I also collected the prices of similar items today.

This is what I need you to do!

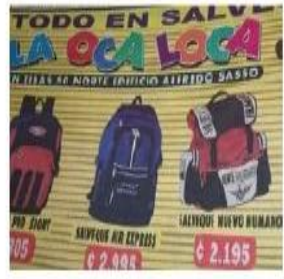

Pigura 1. Preclos de salveques hace 10 alloi

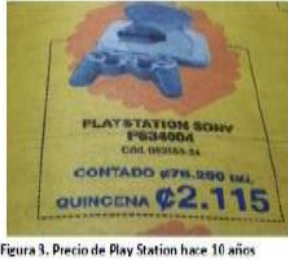

Fieura 3. Precio de Play Station hace 10 año

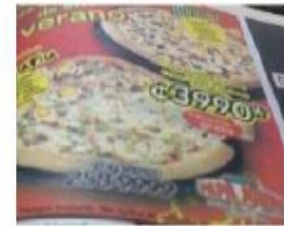

Figura S. Combo Papa Johns hace 10 afios

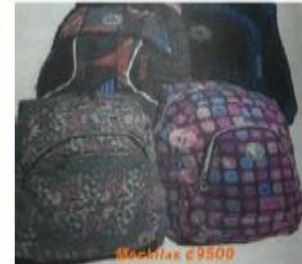

Pigura 2. Precior de salvequesen el 2012

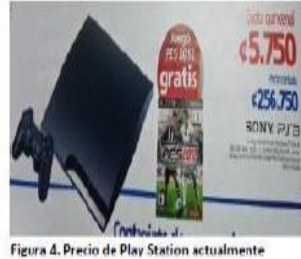

Fieura 4. Precio de Play Station actualmente

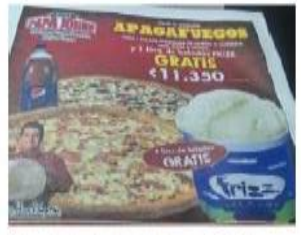

Figura 6. Combo Papa Johns en el 2012 solving method so your mates, in a similar situation, can use your reasoning to determine their current allowances, too.

\section{Procedure and data collection}

During the implementation of mathematical modelling activities, the 24 participating students were divided into subgroups. To make the process as natural as possible, these subgroups were the same as those usually formed during normal class development.

To collect data, we first applied some mathematical modelling activities (Figure 1 and Figure 2). Each activity required four 40-minute sessions. At the beginning of each session, we introduced the activities so students would be familiar with the context. They were asked to write all their answers in a report, and we collected information from students' drafts about their processes. With this, we compiled the written productions of their 
processes. During this application, we observed the students in order to find evidence of the errors they made when solving the activities. One of the researchers was present during the process as a guide in the implementation of the activities, since the main purpose was for students to solve the activities autonomously. The official teacher of the participating group contributed to providing participant data and assisting during the recordings.

We prepared an individual interview with one student from each group, who was randomly selected and asked questions about errors made during task resolution, so we could delve into the written answers, contrast the data, and understand the ambiguous answers. The interviewer was the class teacher so that the students felt comfortable answering.

\section{Data analysis}

Content analysis of the data obtained (Fraenkel, Wallen, \& Hyun, 2011) was carried out. We based our error analysis on the categorisation proposed by Abrate et al. (2006) because we have not found a classification for errors in modelling tasks. Once categorised, they were associated with the modelling phases described in the theoretical framework. Abrate et al. (2006) classified the error into seven categories described above: Errors due to mathematical language $(\mathrm{C} 1)$, Errors due to difficulties in obtaining spatial information (C2), Errors due to incorrect inferences or associations (C3), Errors due to the recovery of a previous scheme (C4), Errors due to incorrect or unintentional calculations (C5), Possible errors due to deficiencies in the construction of prior knowledge (C6), Errors due to the absence of previous knowledge (C7).

\section{RESULTS}

We present below the main results organised in two sections that correspond to each of the activities proposed to the students.

\section{Errors present in the answers to activity 1}

For the first activity (Figure 1), there were 24 students divided into nine groups, six of which were formed of three members, and three groups formed of two students each. Therefore, we had nine different resolutions, of which only two were correct, namely, those of group 1 and group 9.

Table 1 presents information on how groups of students implemented the modelling process phases in activity 1 . 
We noted that six of the nine groups applied the first phase, "description," of the modelling process, i.e., they understood, organised, and systematised the information proposed in the task. In this phase, groups 2 and 4 approached the mathematical model incorrectly, without any previous process other than reading the task (see image 1 of Figure 3). Besides, we highlight the answer given by group 3, which added information (tablespoons of salt, cinnamon, etc.) not provided in the original task (see image 2 of Figure 3).

\section{Table 1}

Implementation of modelling phases in activity 1

\begin{tabular}{|c|c|c|}
\hline $\begin{array}{l}\text { Modelling } \\
\text { phases }\end{array}$ & Evidence & Groups $^{\mathrm{a}}$ \\
\hline \multirow[t]{3}{*}{ Description } & $\begin{array}{l}\text { Organise and systematise information in a } \\
\text { table, scheme, drawing, or step by step. }\end{array}$ & $\begin{array}{l}\text { G1, G5, G6, } \\
\text { G7, G8, G9 }\end{array}$ \\
\hline & $\begin{array}{l}\text { Do not organise the information; pose an } \\
\text { operation straight away. }\end{array}$ & $\mathrm{G} 2, \mathrm{G} 4$ \\
\hline & $\begin{array}{l}\text { Add data that the task did not provide and } \\
\text { organise the information. }\end{array}$ & G3 \\
\hline Handling & Get a math model and solve it. & All \\
\hline \multirow[t]{2}{*}{ Prediction } & $\begin{array}{l}\text { Analyse and interpret the results. Provide an } \\
\text { answer to the problem. }\end{array}$ & $\begin{array}{c}\mathrm{G} 1, \mathrm{G} 2, \mathrm{G} 4, \\
\mathrm{G} 5, \\
\mathrm{G} 6, \mathrm{G} 7, \mathrm{G} 8\end{array}$ \\
\hline & Solve the task, but do not interpret the results. & G3, G9 \\
\hline \multirow[t]{3}{*}{ Validation } & $\begin{array}{l}\text { Display a preliminary review when solving the } \\
\text { task. }\end{array}$ & $\mathrm{G} 3, \mathrm{G} 4$ \\
\hline & $\begin{array}{c}\text { Do not review the incorrect final response, } \\
\text { there are errors. }\end{array}$ & $\begin{array}{c}\mathrm{G} 2, \mathrm{G} 3, \mathrm{G} 4, \\
\mathrm{G} 5, \mathrm{G} 6, \mathrm{G} 7 \\
\mathrm{G} 8\end{array}$ \\
\hline & $\begin{array}{l}\text { Solve the task correctly but do not review the } \\
\text { response. }\end{array}$ & G1, G9 \\
\hline
\end{tabular}

\section{Figure 3}


Example of error in the description stage of the mathematical modelling process $^{2}$

\begin{tabular}{|c|c|}
\hline ¿Coantas tozas dabaría usar? & 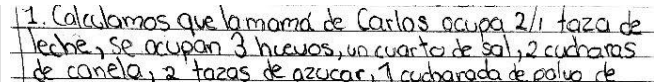 \\
\hline - Is taras de lache $\rightarrow$ Maltiplicarnos $\begin{array}{c}5 \cdot 3 \\
\text { is }\end{array}$ & \\
\hline & 3.20 panesillos. \\
\hline $\begin{array}{l}\text { deor } \\
\text { con } 10\end{array}$ & 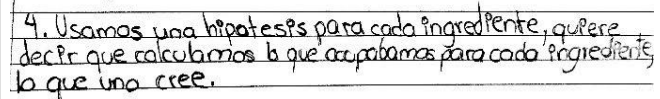 \\
\hline $\begin{array}{l}\text { - La mama de carlos pudo } \\
\text { panecillos } \rightarrow \text { Mulifiplicamos }\end{array}$ & $2 \times 5=10 \div 5-3=2$ \\
\hline 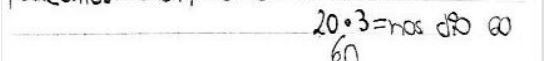 & $3 \times 5=15-10=$ \\
\hline
\end{tabular}

For the second phase of the modelling, the manipulation process, all groups formulated a mathematical model and solved it. When analysing the information obtained at this stage, we found various errors for each of the following categories: errors due to incorrect inferences or associations, errors due to incorrect or unintentional calculations, and errors due to the recovery of a previous scheme. Table 2 summarises these errors that the participants and the groups made in activity 1 .

\section{Table 2}

Errors present in the responses to activity 1

\begin{tabular}{lll}
\hline Categories & Errors in activity 1 & Groups $^{*}$ \\
\hline
\end{tabular}

\footnotetext{
${ }^{2}$ How many cups of milk should she use? How many rolls could my mom prepare with the flour?

Carlos's mom could prepare 60 rolls $\rightarrow$ we multiplied 20 x 3

1. We calculated that Carlos's mom used $2 / 1$ cups of milk, 3 eggs, $1 / 4$ salt, 2 spoons cinnamon, 2 cups of sugar, 1 spoon raising flour.

2. 3 cups of flour

3. 20 rolls

4. Use one hypothesis for each ingredient, i.e., we calculated what we used for each ingredient we believe.
} 


\begin{tabular}{|c|c|c|}
\hline $\begin{array}{l}\text { C3. Errors due to incorrect } \\
\text { inferences or associations }\end{array}$ & $\begin{array}{l}\text { Perform arithmetic operations } \\
\text { regardless of context. }\end{array}$ & G6, G4 \\
\hline & Add data: four cups of milk. & G6 \\
\hline $\begin{array}{l}\text { C4. Errors due to the } \\
\text { recovery of a previous } \\
\text { scheme }\end{array}$ & $\begin{array}{l}\text { Error confusing the division of natural } \\
\text { numbers with that of decimal numbers } \\
16.5 \text { divided by } 20 \text {. }\end{array}$ & G5 \\
\hline \multirow[t]{6}{*}{$\begin{array}{l}\text { C5. Errors due to incorrect } \\
\text { or unintended calculations }\end{array}$} & Missing correspondence $3=1$ & G8 \\
\hline & Error entering correspondence $3=0.5$ & G8 \\
\hline & Error raising operation $16.5 \div 3$ & G8 \\
\hline & Incorrect reading "a cup of milk". & $\mathrm{G} 3, \mathrm{G} 4$ \\
\hline & $\begin{array}{l}\text { In correspondence } 3=1 \text {, they get half } \\
\text { of } 3 \text {, but in correspondence } 1 \text { they } \\
\text { write "a quarter" instead of "half". }\end{array}$ & $\mathrm{G} 2$ \\
\hline & $\begin{array}{l}\text { Error setting correspondence } 20=1, \\
\text { they add } 7.5 \text { instead of } 10 .\end{array}$ & $\mathrm{G} 2$ \\
\hline C8. Other & $\begin{array}{l}\text { Add data that the task did not } \\
\text { knowingly provide. }\end{array}$ & G3 \\
\hline
\end{tabular}

* G1 through G9 are the codes assigned to each group of students.

The category of errors due to incorrect inferences or associations was observed in the responses of groups G4 and G6. G6's (Figure 4) answer included operations regardless of the meaning of the data. For example, students added $3+16.5$ without noting that 3 represents the number of flour cups and that these cups are within the 16.5 cups of flour. 


\section{Figure 4}

Example of error due to incorrect inferences or associations ${ }^{3}$.

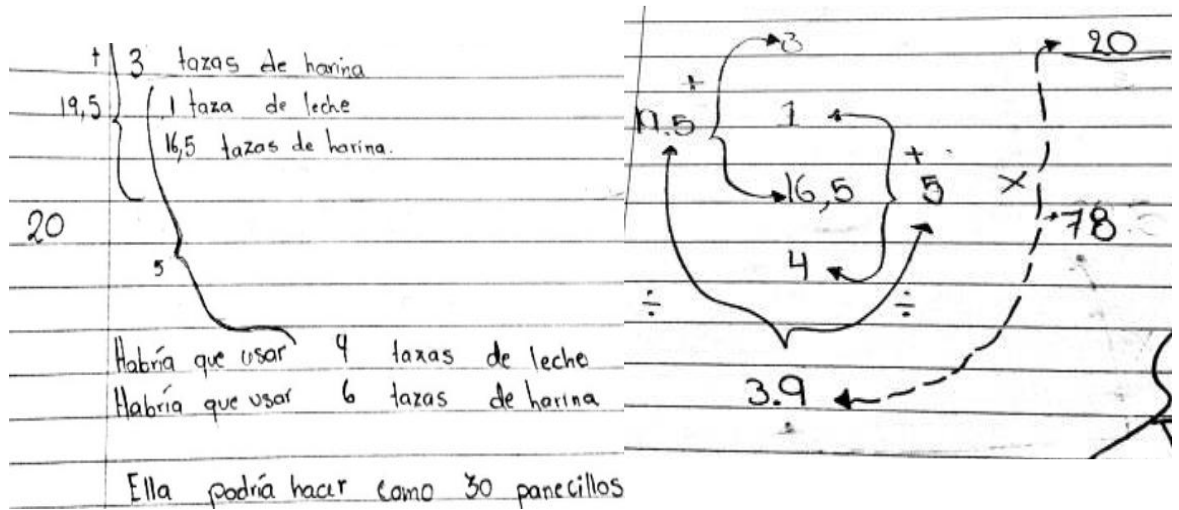

Faced with this process, one of the members of this group was interviewed about the students' answer:

Teacher: Which operations did you perform to obtain the 19.5 that appears in the resolution?

Student: We added 16.5 plus 3 flour cups, and this resulted in 19.5 flour cups.

Student: Then we added 1 plus 4 cups of milk, which gave us 5 cups of milk.

Teacher: Why did you use that procedure?

Student: Well, the idea was to make more flour, make more ingredients to get more bread.

In the same answer, students in G6 considered four cups of milk that the task statement does not mention, and they added one cup of milk, resulting in five cups of milk, which represents an incorrect inference.

\section{${ }^{3} 3$ cups of flour \\ 1 cup of milk \\ 16.5 cups of flour}

She should use 4 cups of milk

She should use 6 cups of flour

She could make around 30 rolls 
Group 4 proposed a similar response. They multiplied the quantity of 20 rolls by the 3 cups of flour, concluding that 60 is the number of bread rolls corresponding to 16.5 cups (see image 1 of Figure 3), making incorrect associations.

About the category errors due to the recovery of a previous scheme, we found an example in group 5's answer shown in Figure 5. Here, the students used the algorithm of the division of natural numbers to carry out the division of numbers 16.5 by 20 , using an ancient knowledge scheme. During this process, these participants created a technique to solve the operation because they did not know how to do it. Students also describe the process as follows: "We thought we could divide 16.5 cups of flour between the 20 rolls and the total was 825 rolls," mixing up decimal numbers with natural numbers.

Regarding the category errors due to incorrect or unintended calculations, in Figure 5, where group 8's answer is shown, students present the symbolic correspondence $3=1$, i.e., three cups of flour corresponding to one cup of milk. The solution is incorrect because correspondence $3=1$ appears four times, one more correspondence is missing, so it is categorised as incorrect or unintended calculation. Another error was to enter correspondence $3=0.5$ where, in the right part of the correspondence, they divide the unit in half, but the left part is unchanged.

\section{Figure 5}

Examples of errors of activity $1^{4}$

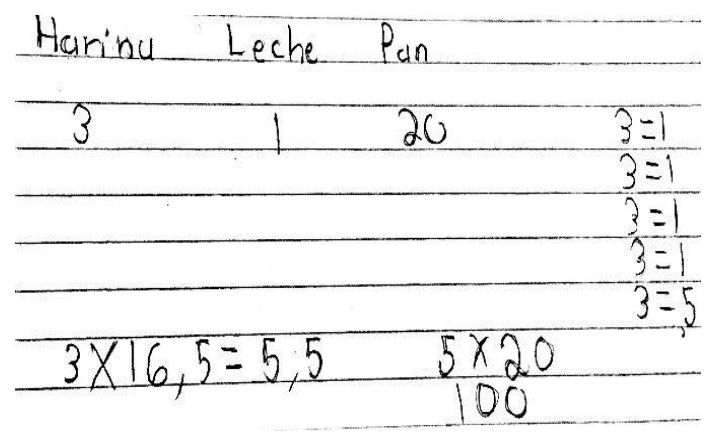

${ }^{4}$ Flour - milk - bread rolls 
Another example of this type of group 8 error is evidenced in Figure 5. The product 3 by 16.5 is incorrect, because the students wanted to raise a ratio of 16.5 per 3 for the flour cups, which will coincide, in this case, with the correct amount of cups of milk. These students were wrong in the sign of the operation and the order of the elements, but not in the result; so, it was an oversight when writing their processes.

We can see another example of this same category in group 2's answer, revealed in the two images of Figure 6. The participants give as an answer "5 cups of milk and a 1/4 of milk," in which we infer that they consider that every three cups of flour equals one cup of milk. Also, students get half of the three cups of flour, but this same operation is not done with one cup of milk, since they incorrectly write "a quarter of milk or $\frac{1}{4}$ ". To find the number of rolls, the participants applied the same reasoning used when obtaining the quantity of milk, but it is done incorrectly because in the last step, half of 20 had to be used, and it was not so.

\section{Figure 6}

Example of error due to incorrect calculation when solving activity $1^{5}$

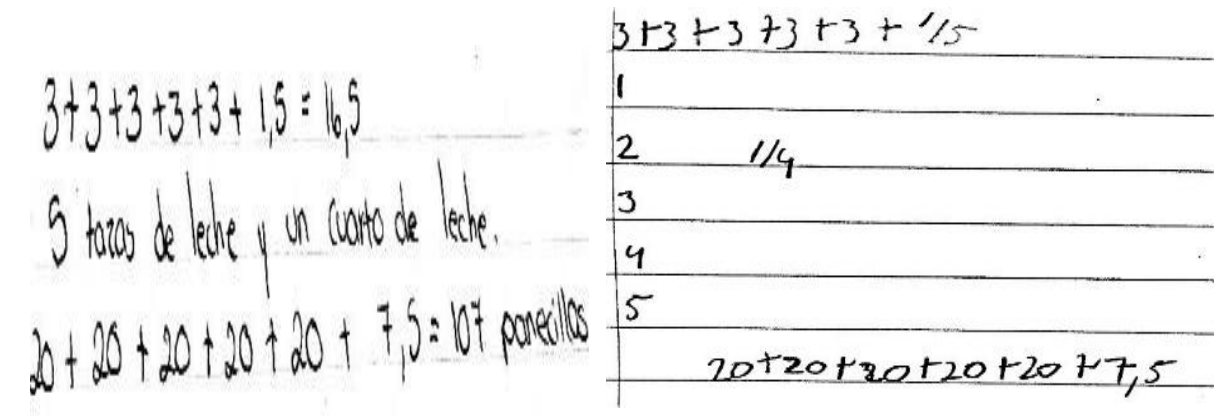

On the other hand, we highlight the answer given by group 3 . They added information (tablespoons of salt, cinnamon, etc.) that the original task did not provide, resolving the activity using both the data supplied and the data invented.

55 cups of milk and a quarter of milk bread rolls 
In the mathematical modelling prediction phase, seven of the nine groups interpreted and analysed the results relative to the data provided in the task. Two of the groups, group 3 and group 9, skipped this phase. Although group 9 gave one of the two correct solutions to the problem, it did not interpret the answer. In image 2 of Figure 3, group 3 resolution is presented as an example of this error type.

In the validation phase, we obtained that during the task resolution process, only two of the groups, G3 and G4, neglected information present in the statement when acquiring the quantity of milk mentioned in the task. This error is categorised as an unintended error and is conceived in the second stage of the modelling process. The groups fix their mistake by managing to find the quantity of milk they occupied and provide a solution. No evidence was obtained from the revision of the final answers. We found errors that could have been corrected if students had reflected on their answers and received feedback of the resolutions.

\section{Errors present in the responses of activity 2}

For the second activity (Figure 2), 22 students participated, two less than in the previous one, because they missed class that day. Six groups of three and two groups of two students were formed, generating eight different answers, all of them incorrect.

Table 3 presents the information corresponding to the phases of the mathematical modelling process performed by the different groups of students when solving activity 2 .

\section{Table 3}

Implementation of modelling phases in activity 2

\begin{tabular}{ccc}
\hline $\begin{array}{c}\text { Modelling } \\
\text { phases }\end{array}$ & Evidence & Groups \\
\hline Description & $\begin{array}{c}\text { Organise and systematise information in a } \\
\text { table, scheme, drawing, or step by step. } \\
\text { Do not organise the information, pose an } \\
\text { operation straight away. }\end{array}$ & $\begin{array}{c}\text { G1, G2, G4, G6, } \\
\text { G7, G8 }\end{array}$ \\
Handling & Get a math model and solve it. & G1, G2, G3, G5, \\
& & G7, G8, \\
\hline
\end{tabular}




\begin{tabular}{ccc}
\hline & $\begin{array}{c}\text { Partially solve the mathematical model. } \\
\text { Analyse and interpret the results. Provide } \\
\text { an answer to the problem. }\end{array}$ & G4, G6 \\
& $\begin{array}{c}\text { Solve the task, but do not interpret the } \\
\text { results. }\end{array}$ & G1, G2, G6, G8 \\
Validation & Do not review the problem, errors are \\
found. & All \\
\hline
\end{tabular}

G1 through G9 are the codes assigned to each group of students.

In the first phase, description, six of the eight groups organised and systematised the task data, making tables and diagrams, among others. Two of the groups, G3 and G5, did not simplify the task information but posed a mathematical model incorrectly straight away. In the following figure, group 3 answer is shown as an example.

\section{Figure 7}

Example of error in the description stage of the mathematical modelling process $^{6}$

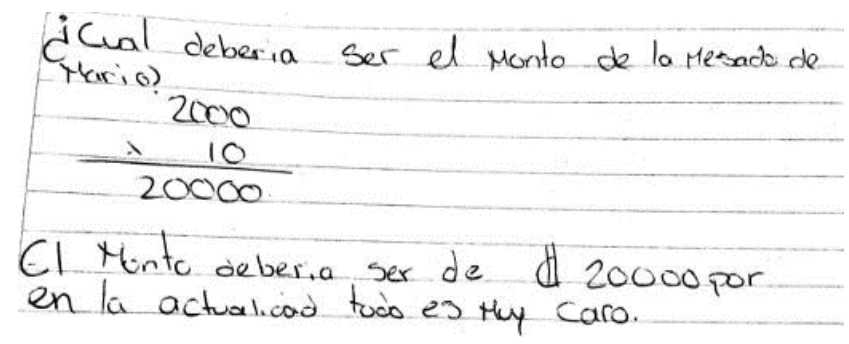

For the second phase, manipulation, six of the eight groups created a mathematical model and solved it. Group 6 obtains a distinct mathematical model for two of the three articles present in the task, leaving aside one of the articles, so relevant information for the resolution is omitted. G4 provides an approximate answer to the task solution (see Figure 8) without creating a mathematical model.

\footnotetext{
${ }^{6}$ Which should Mario's allowance be? The amount should be $\mathbb{C} 2,000$ because everything is too expensive nowadays.
} 


\section{Figure 8}

Example of error in the description stage of the mathematical modelling process $^{7}$

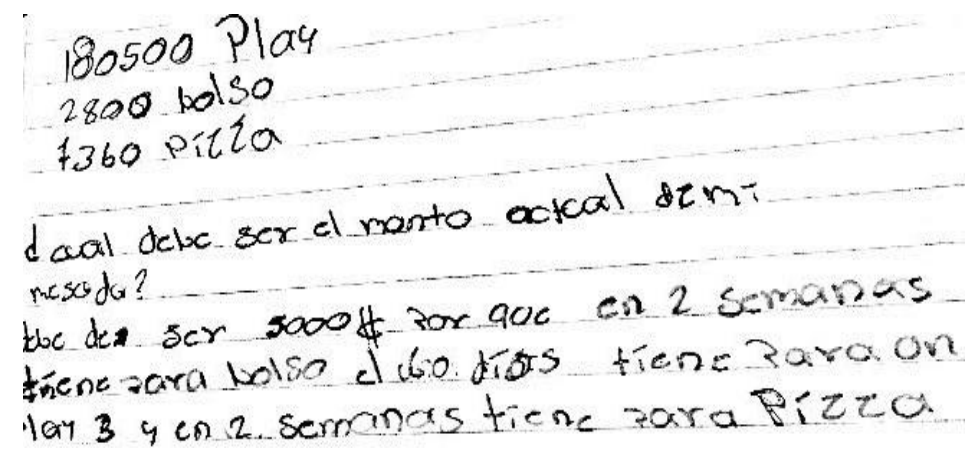

Besides, at this stage, we found mathematical errors that were classified into three categories: errors due to incorrect inferences or associations, errors due to the recovery of a previous scheme, and errors due to incorrect or unintended calculations. Table 4 summarises the several errors and the groups that made them.

\section{Table 4}

Types of errors present in the answers to activity 2

\begin{tabular}{ccc}
\hline Categories & Errors in activity 2 & Groups" \\
\hline $\begin{array}{c}\text { C3. Errors due to incorrect } \\
\text { inferences or associations }\end{array}$ & Incorrect increases. & G1, G3, \\
& $\begin{array}{c}\text { Set 13.19 as an exact amount. } \\
\text { Confuse the "comma" of the thousand } \\
\text { units with the decimal "dot". }\end{array}$ & G1 \\
& G1 \\
\hline
\end{tabular}

\footnotetext{
${ }^{7}$ Which should be the current allowance? It should be $\mathbb{C} 5,000$ because in 2 weeks he has for pocket money [...] he has for 3 and 2 weeks has for pizza.
} 
C4. Errors due to the recovery of a previous scheme

C5. Errors due to incorrect or unintended calculations
Error performing the operation division of natural numbers.

Take some data from the table incorrectly.

G2

They wrote 13.19 instead of 1.319 .

G1 through G9 are the codes assigned to each group of students.

As for the category of errors due to incorrect inferences or associations, this was the most common in the answers. Particularly, five of the eight groups participating in this activity used operations without a valid path and concluded that the final result was the increase in the amount of the allowance to be made. Figure 9 shows an example of the answer proposed by group 1 students.

\section{Figure 9}

Example of error of the type incorrect associations when solving activity $2^{8}$

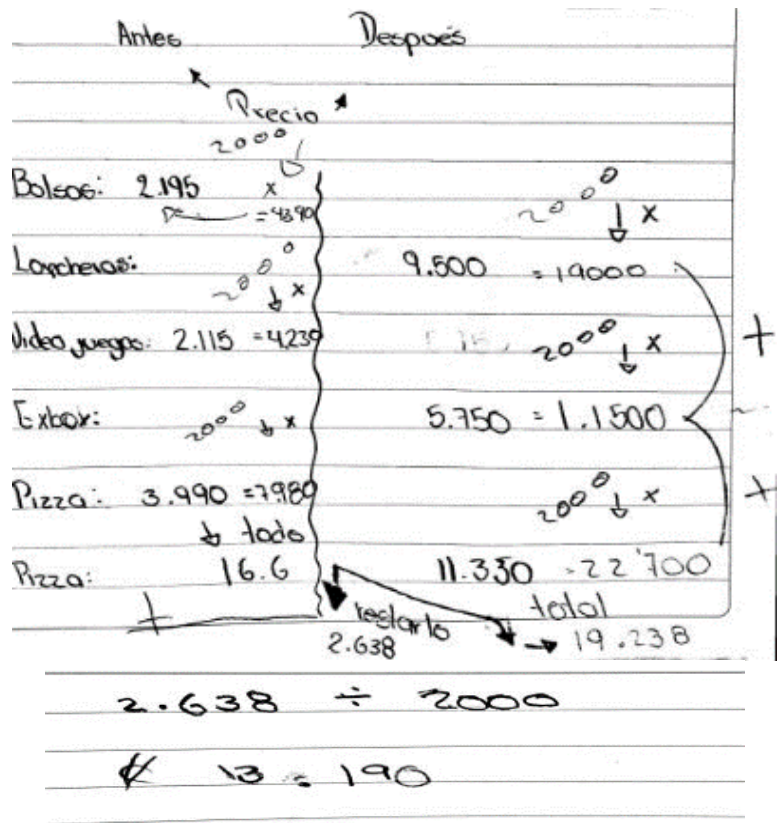

${ }^{8}$ Before - After $\rightarrow$ Price - bags - lunch box - videogames - Xbox - pizza 
When analysing the information from the previous answer, we found that the students mix up the commas that separates the units of thousands with the dot that separates the decimal part, making an incorrect inference. We also realised that there is no clear and argued path that justifies the reasoning used by the students, which was revealed through an interview with the participants of the group.

Teacher: What did you do in the first steps of the solution?

Student: We split prices in two, past prices and current prices. We multiplied each by $\mathbb{C} 2,000$, because the little one was given $\mathbb{C} 2,000$ and now the prices are higher.

Student: We added up all the results of the multiplications and subtracted the results, this gave us $\mathbb{C} 2,638$.

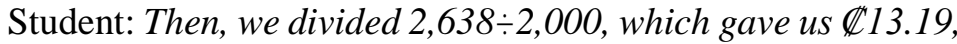
which is an exact amount.

Student: We did this so that we would have an exact amount, for what he is going to buy in a week, because the problem was that every week he was given $\mathbb{C} 2,000$, so we had to increase the monthly allowance.

Thus, in the results above, they incorrectly infer that by multiplying each of the prices by the allowance, Mario (the character of the activity) would receive more money. Another error is their subtracting the totals of the prices, multiplying them by $\mathbb{2} 2,000$, and re-dividing by this same amount. Furthermore, the student stated that the correct answer was 13.19, which is also a fallacy in his reasoning.

Likewise, we observed other errors of incorrect associations such as the answer in Figure 7, where, to calculate Mario's allowance, group 3 multiplied the allowance received ten years ago by the number of years that have elapsed, obtaining $\mathbb{2} 20,000$, incorrectly assuming that the increase is the same for all years.

To these errors, we also added the one found in group 7's answer, as shown in Figure 10. Here, they add the prices of the current items to the prices of the items ten years ago, obtaining as a result $\mathbb{C} 36,000$. Subsequently, they

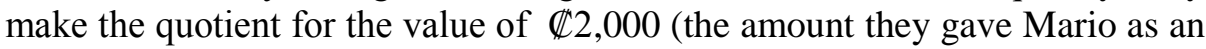
allowance), obtaining $\mathbb{C} 18,000$ as a final result. Students conclude that this amount is the current increase in Mario's allowance: "Mario must have his 
allowance increased to $\mathbb{1} 18,000$ per fortnight because of the price increase." Group 5 and 8 answers were very similar to the one described.

\section{Figure 10}

Errors obtained to solve activity 2 due to incorrect assumptions

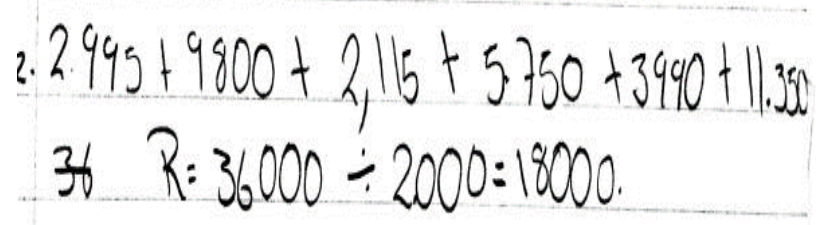

Regarding errors due to incorrect or unintended calculations, we classify the answer of group 2 in this category. In one of them, the students added the value of the items ten years ago. Then, they considered the price of the biweekly instalment of the Playstation, which corresponds to $\mathbb{C} 2,115$, but by performing the same procedure with the current prices, the group wrongly considers the cash share of $\mathbb{C} 256,750$, instead of the biweekly share. This process is reaffirmed with the data provided by the interview conducted with one of the students:

Teacher: Did you see that in the images of the articles ten years ago and the current ones of Playstation, there were two prices, the price per fortnight and the spot price?

Student: No teacher, in the Playstation image ten years ago, we only saw that one (pointing to $\mathbb{C} 2,115$ ) and in the other, we just saw the very high price, the current one (referring to the spot price of the article, of $\mathbb{C} 256,750)$.

Another example of this category can be seen in Figure 9, which shows the solution made by group 1 . There, we observed that when carrying out the operation $2,638 \div 2,000$, they obtained the incorrect result of $\mathbb{C} 13.19$, since it should be $\mathbb{C} 1.319$, so they made an error when positioning the dot.

Like activity 1 , one of the answers to activity 2 presents an error due to the recovery of a previous scheme, evidenced in Figure 10. The figure shows the solution given by group 7 , in which the operation $36,000 \div 2,000$ is visualised. They obtained the incorrect result of $\mathbb{C} 18,000$, because they confused the previous division $36,000 \div 2=18,000$, and are not aware that the operations are different. 
In the third phase of the modelling process, the prediction of the mathematical modelling problem, three of the nine groups, after solving the mathematical model and giving a possible answer, provided an interpretation using the problem hypotheses (see Figure 7 and Figure 8). Group 4 did not create the mathematical model but provided an approximate answer (see Figure 8), subsequently interpreting it. Four of the groups did not apply this stage, just showing a numerical solution without connection with the conditions given in the problem (see Figure 9).

Finally, we observed that all the resolutions were incorrect, with errors. None of the groups applied the fourth phase of the modelling process to validate the answers provided.

\section{DISCUSSION AND CONCLUSIONS}

The data obtained show that, in general, the participating groups did not apply all phases of the mathematical modelling process. Concerning each of the phases, we found that two of the groups omitted the first phase, description, in both activities. They promptly proposed the mathematical model without carrying out a previous systematisation of the information. For activity 2 , the opposite happened, two of the groups omitted the construction of the mathematical model and its resolution (second phase of mathematical modelling), but they did execute the first phase. About the third phase, prediction, two of the groups in activity 1 and four of the groups in activity 2 omitted this phase when conceiving a numerical answer, rather than interpreting or specifying the process to reach it, which suggests that they have been exposed to a teaching where the final answer is prioritised, rather than the process to reach it. We should note that for activity 1, only two of the answers obtained were correct, and for activity 2, none was correct. Finally, for the fourth stage, the validation of the mathematical modelling process, in activity 1 , only two of the groups carried out a preliminary revision when formulating the mathematical model, that is, during the second phase. However, none of the groups made a reflection and judged the feasibility of the final solution obtained. Similarly, with activity 2 , the fourth stage of the modelling process was not applied.

According to Abrate et al.'s (2006) classification, the most frequent error category in the responses was errors due to incorrect or unintended calculations in the first modelling activity. Within this category, groups of students neglected information present in the statement - the quantities needed in the resolution process- and did not use all the data. In the second activity, 
the most visible error category was errors due to incorrect associations (with incorrect increases). Coinciding with the results by Fernandez and Brey (2012), Isik and Kar (2012), and Socas et al. (2016), other types of errors correspond to confusion students made between the comma that separates the units of thousands with the dots that separates the decimal part, and incorrectly solving basic arithmetic operations by recovering an old scheme of knowledge (such as confusing the division operation with natural numbers with that of decimal amounts).

The data obtained in the interviews showed that, for the most part, the errors could have been overcome if the students had carried out the validation stage of the solution of the problem, i.e., a review of the mathematical processes should have been carried out during or at the end of the cyclical modelling process. This result, as in previous research (Fernández \& Brey, 2012; Guerrero, 2016; Socas et al., 2016), seems to be a common fact at distinct educational levels, so we believe that teaching must influence the management of this phase (Brown et al., 2016; Fernández \& Brey, 2012; Ruano et al., 2008; Socas et al., 2016). At the same time, it is necessary to investigate why the students did not apply this phase (Socas et al., 2016).

One of the answers is noteworthy, it does not correspond to any of the categories of Abrate et al. (2006). In this answer, students solve the activity using the data of the statement and invented data. We believe that the peculiarity of this answer is due to the type of activity (mathematical modelling) and the teaching on modelling that students have received, where it is usual to find non-routine and open tasks (in which data must be collected and there is not a single correct solution). In this sense, it is necessary to expand research with more students, since the particularities presented by students who have been taught modelling are still unknown.

We interpreted the results aware of the limitations of the work, the specificity of the context where the research is carried out, the sample of participants, and that the number of activities does not allow us to establish generalisations. Without overlooking these limitations, we have obtained valuable information to improve modelling teaching. Although errors depend on the task presented and its content, the coincidences detected in other works (Fernández \& Brey, 2012; Guerrero, 2016; Isik \& Kar, 2012; Ruano et al., 2008; Socas et al., 2016) show the need to pay special attention to the prevention and treatment of errors found in representations and resolution of arithmetic operations. The errors detected in this work are elements of reflection, progress, and feedback that should encourage teachers' search for 
strategies that help solve the deficiencies that emerge during modelling activities. Furthermore, it is necessary to emphasise the teaching of the stages of the cyclical modelling process, particularly aware of the need to reflect on the process followed, the reasonableness of the solution, and its validation.

Finally, we conclude that it is essential that teachers analyse the problem structure in detail, anticipating possible schoolchildren's errors (Çalişici, 2018; English, 2007; Socas et al., 2016), and propose significant learning experiences for the student (Socas, 1997). In that sense, mathematical modelling activities are appropriate because they contain real-life situations close to the students and stimulate creative thinking and problem solving skills.

\section{ACKNOWLEDGEMENTS}

Work carried out with the support of project PCG2018-095765-B-100 of the Plan Nacional de I+D+I (MICINN).

\section{AUTHORSHIP CONTRIBUTION STATEMENTS}

K.P.L. has contributed to error study and mathematical modelling, design, task implementation, data analysis, and final text writing. E.C.-R. has reviewed and corrected the data design and analysis, advising on specific situations and has collaborated in drafting the final text.

\section{DATA AVAILABILITY STATEMENT}

The data are kept in the authors' archives, the first author being in charge of their custody and consultation by the interested parties.

\section{REFERENCES}

Abrate, R., Brate, R., Pochulu, M. y Vargas, J. (2006). Errores y dificultades en Matemática: Análisis de causas y sugerencias de trabajo (1 era ed.). Universidad Nacional de Villa María.

Araya, R. (2016). STEM y modelamiento matemático. Cuadernos de Investigación y Formación en Educación Matemática, 11(15), 291-317. 
Bosch, M., García, F. G., Gascón, J. y Higueras, L. R. (2006). La modelización matemática y el problema de la articulación de la matemática escolar. Una propuesta desde la teoría antropológica de lo didáctico. Revista Educación Matemática, 18(2), 37-74.

Blum, W. y Niss, M. (1991). Applied mathematical problem solving, modelling, applications, and Links to Other Subjects. Educational Studies in Mathematics, 22, 37-68. https://doi.org/10.1007/BF00302716

Brown, M., Bossé, M. J. y Chandler, K. (2016). Student Errors in Dynamic Mathematical Environments, International Journal for Mathematics Teaching and Learning, 17(1), 1-27.

Çalişici, H. (2018). Middle School Students' Learning Difficulties in the Ratio-proportion Topic and a Suggested Solution: Envelope Technique. Universal Journal of Educational Research, 6(8), 1848-1855. http://doi.org/10.13189/ujer.2018.060830

English, L. D. (2007) Interdisciplinary modelling in the primary mathematics curriculum. In Watson, J.; Adams, V. M. (Eds.) Proceedings of the $30^{\text {th }}$ Mathematics Education Research Group of Australasia Annual Conference (pp. 275-284). Tasmania: Universidad de Launceston.

Fernández, A. y Brey, R. (2012). Errores en el aprendizaje de las matemáticas financieras. Enseñanza de las ciencias, 30(2), 7392.

Fraenkel, J. R., Wallen, N. E. y Hyun, H. H. (2011). How to design and evaluate research in education. McGraw-Hill.

Guerrero, F. (2016). Errores matemáticos en la resolución de problemas de modelización matemática. Caso: Estudiantes del primer año de educación media. Revista ciencias de la educación, 26(47).

Isik, C. Y Kar, T. (2012). The Analysis of the problems posed by the preservice teachers about equations. Australian Journal of Teacher Education, 37(9). http://doi.org/10.14221/ajte.2012v37n9.1

Lesh, R. y Doerr, H. M. (2003). Foundations of a models and modeling perspective on mathematics teaching, learning and problem solving. In: Lesh, R.; Doerr, H. M. (Eds.), Beyond Constructivism: Models and Modeling Perspectives on 
Mathematics Problem Solving, Learning, and Teaching (pp. 333). Lawrence Erlbaum.

López, R.; Molina, M. Y Castro, E. (2017). Modelización en el aula de ingeniería: un estudio de caso en el marco de un experimento de enseñanza. $P N A, 11(2)$, 75-96.

Magen-Nagar, N. (2016). Examining Teaching Based on Errors in Mathematics Amongst Pupils with Learning Disabilities. European Journal of Science and Mathematics Education, 4(4), 506-522.

Ministerio de Educación Pública de Costa Rica. (2012). Programas de estudio en matemática para la educación general básica y el ciclo diversificado.

Movshovitz-Hadar, N., Inbar, S. y Zaslavky, O. (1987). An empirical classification model for errors in high school mathematics. Journal for Research in Mathematics Education. National Council of Teachers of Mathematics, 18(1), 3-14. http://doi.org/10.2307/749532

Porras, K. (2013). Modelaje matemático como método de investigación en las clases matemáticas. In: Octavo Congreso Internacional de Enseñanza de la Matemática Asistida por Computadora (pp. 104-115). Cartago: Instituto Tecnológico de Costa Rica. https://www.tec.ac.cr/sites/default/files/media/doc/08 memoria 1.pdf

Porras, K. y Fonseca, J. (2015). Aplicación de actividades de modelización matemática en la educación secundaria costarricense. Uniciencia, 29(1), 42-57.

Programa Estado de la Nación. (2017). Sexto Informe Estado de la Educación. San José: Programa Estado de la Nación del Consejo Nacional de Rectores.

Radatz, H. (1980) Students' errors in the mathematical learning process: a survey. For the Learning of Mathematics, 1(1), 16-20.

Rico, L. (1998). Errores en el aprendizaje de las matemáticas. En Kilpatrick, J.; Gómez, P.; Rico, L. (Eds.). Educación Matemática. Errores y dificultades de los estudiantes. Resolución de problemas. Evaluación Historia (pp. 69-108). Una empresa docente. 
Ruano, R. M., Socas, M. M. y Palarea, M. M. (2008). Análisis y clasificación de errores cometidos por alumnos de secundaria en los procesos de sustitución formal, generalización y modelización en álgebra. $P N A, 2(2), 61-74$.

Stake, R. E. (2010). Qualitative Research. Study how things work (1era ed.).

Socas, M. (1997). Dificultades, obstáculos y errores en el aprendizaje de las matemáticas en la Educación Secundaria. In: Rico, L. (Ed.). Educación Matemática en la Enseñanza Secundaria (pp. 15-38). Horsori.

Socas, M. (2007). Dificultades y errores en el aprendizaje de las matemáticas. Análisis desde el enfoque lógico semiótico. En: Camacho, M.; Flores, P.; Bolea, M. P. (Eds.), Investigación en Educación Matemática XI (pp. 19-52). Tenerife: Sociedad Española de Investigación en Educación Matemática, SEIEM.

Socas, M., Ruano, M. R., Hernández, J. (2016). Análisis Didáctico del proceso matemático de Modelización en alumnos de Secundaria. Avances de Investigación en Educación Matemática, 9, 21-41.

Sriraman, B. y Lesh, R. (2006). Modeling conceptions revisited. Zentralblatt für Didaktik der Mathematik, 38(3), 247-254. 